Article

\title{
From Short Food Supply Chains to Sustainable Agriculture in Urban Food Systems: Food Democracy as a Vector of Transition
}

\author{
Yuna Chiffoleau ${ }^{1, *}$, Sarah Millet-Amrani ${ }^{1}$ and Arielle Canard ${ }^{2}$ \\ 1 Joint Research Unit “Innovation and Development in Agriculture and Food", French National Institute for \\ Agricultural Research, Montpellier 34060, France; sarah.millet-amrani@supagro.fr \\ 2 Freelance consultant, Montpellier 34000, France; arielle.canard@gmail.com \\ * Correspondence: chiffole@supagro.inra.fr; Tel.: +33-499-961-2884
}

Academic Editors: Giaime Berti, Moya Kneafsey, Larry Lev, Irene Monasterolo and Sergio Schneider Received: 31 May 2016; Accepted: 20 October 2016; Published: 28 October 2016

\begin{abstract}
In industrialized nations, local food networks have generally been analyzed through alternative food systems, in spite of the fact that they are much more diverse than this would imply. In France, 'short food chains' are both a continuation of a long tradition and a recent trend which now extends beyond activists, to consumers and producers as well. This paper will explore the conditions under which these chains can change the practices and knowledge of ordinary actors in urban food systems, from producers to urban consumers and policy-makers, in the area of agriculture and sustainability. It will consider the case study of the creation and development of an urban open-air market which has been analyzed using intervention research with input from economic sociology. We will highlight how personal relations, which are encouraged by a participatory context, support the evolution of practices and knowledge. We will also illustrate how a system of produce labelling has emerged as a mediation resource, and has increased changes as well as participation within the re-territorialization of the urban food system. By describing a concrete expression of food democracy which is spreading in France via a free collective trademark, and by showing its role in the transition of 'ordinary' actors towards a more sustainable agriculture, this paper will shine new light onto local food chains as well as traditional short food chains, and will call for more research on the subject.
\end{abstract}

Keywords: short food chains; urban food systems; food democracy; re-territorialization; food labelling; sustainability; transition; non-activists; economic sociology; intervention research

\section{Introduction}

Since the 1990s in industrialized nations, 'alternative' food networks have generally been studied in the light of initiatives questioning the mainstream agro-industrial model [1]. Although their alternative dimension has been discussed [2,3], all these initiatives share the same 'promise' of more sustainable ways of producing, processing, and/or selling food [4] which demonstrate a 'turn to quality' in both agriculture and consumption [5]. Two types of alternative initiatives were initially examined: fair trade and 'local food networks'. However, by limiting the focus to Community-Supported Agriculture systems (CSAs), farmers' markets, or community gardens, research into alternative local food networks gave little consideration to how these initiatives may change the practices of their stakeholders, as cases often imply 'engaged' actors with responsible behaviors regarding sustainability. Moreover, the agricultural dimension of these networks remains little studied beyond general references to organic farming [6]. A more recent field of research has enlarged the scope of 'alternative' food chains by going beyond contesting direct-to-consumer channels, and analyzing the development of 'values-based supply chains' [7] as intermediate chains in which actors share a commitment to social, environmental, and/or economic values. As these chains are dedicated to 
providing high quality, regional food to consumers, they are more likely to be procured by mid-scale agriculture, and one of their values is therefore to support 'middle-agriculture' whose decline in the United States has been the object of new concerns [8]. This increase in scope has emerged recently in France as well, through the concept of 'mid-tier' chains [9], which can also be considered as a new contribution to the older body of research on the subject of 'economy of quality' in the agrifood sector [10]. However, in these chains, the quality of the produce is a prerequisite, and consumers are willing to pay for specific values that they are aware of, although more could be done in matters of communication [7]. Consequently, research into these chains does not primarily concern itself with how they could encourage the reconnection of production and consumption with quality and values, and to what extent it could affect production or consumption practices. The aim of this paper is therefore to explore the conditions under which local food chains in urban food systems can bring about an evolution in the practices and knowledge of 'ordinary' actors with no or limited skills in agriculture and/or awareness of sustainability, towards a more sustainable agriculture. In this paper, urban food systems will be considered using the definition of a food system as the way in which people organize in order to produce, distribute, and consume their food' [11], from the perspective of urban and peri-urban consumers, and not limited to urban agriculture.

Our contribution will consider France in general, and the case study of an open-air market in particular, whose innovative management, developed stage by stage by ordinary actors who are learning as they go along, is now spreading throughout France by means of a free collective trademark, thus creating a tool for food democracy [12]. This paper will be structured as follows: in the first section, we will begin by briefly describing the context of our case study through a presentation of the history of short food chains and the place they occupy today in France. Then we will present the basic idea in economic sociology theory from which we developed our research: that economic activities are embedded in social structures [13]. In the second section, we will present our material and methods. In the third section, we will develop the trajectory of the open-air market, showing how relations and a labelling system as a mediation resource have encouraged learning processes towards sustainable agriculture. In the last section, we will discuss our results regarding research into alternative food chains as well as issues in economic sociology, and we will call for a further analysis of concrete expressions of food democracy open to 'ordinary actors' in urban food systems.

\section{Context and Theoretical Background}

\subsection{From Alternative to Short Food Chains, Back to Beginnings in France}

In industrialized nations, the focus on alternative food systems in scientific literature hides a larger reality about local food networks. In France for instance, as well as in Southern and Eastern Europe, there is a long-standing tradition of direct local selling: the first Roman forums of antiquity were physical market places where local farmers sold their produce to inhabitants [14]. Although the importance of local markets decreased with the development of Rome, giving way to wholesale trade, they were reinvented in the Middle-Ages in occidental countries as public devices, under the direction of kings [15]. They became neighborhood markets between cities and the countryside; they were privileged places for artisans and sellers who bought directly from local farmers. These 'short food chains' combined small-scale trade with sociability practices, while the market economy developed with external trade and foreign traders [15]. However, in the 18th Century, local markets were not throwbacks to archaic forms of sociability; they were strategic outlets, especially for large or small-scale local farmers [16]. They also maintained an important social function and, for local authorities, constituted privileged instruments for local development. Their role naturally decreased with the industrialization of Europe and the development of long-distance transportation, urbanization, and technical advances. These encouraged an 'agricultural revolution' (or the implementation of productivist logic) and major changes in the type of food consumed with the appearance of processed food, as well as in the organization of food distribution [17]: mass distribution started its spectacular 
ascent in the 1960s when the import of the US model of supermarkets to Western Europe offering low prices through mass sale, self-service, and the suppression of 'small' intermediaries [18]. This development damaged the structuring sector of consumption cooperatives in France, although this movement maintained a significant weight in other European countries such as Italy and Sweden [19].

In France in the 1960s and 70s, although small-scale farms were the first farms to disappear, non-industrial agriculture continued in two different forms: the first was closely associated with 'produce of origin' (the system of 'geographical indications' created in 1905 and developed under the direction of the State) and was widely used in the cheese and wine sectors; here, the AOC (Appellation d'Origine Contrôlée) or IGP (Indication Géographique Protégée) label was mainly used by producers to reach beyond local markets, and to guarantee a specific quality in long chains, supermarkets, and international trade [20]. Conversely, the second form related to subsistence farming and relied on direct selling in farm and local markets. Some of its actors tried to form resistance movements through 'peasant struggles', and were augmented by new-comers who promoted a 'return to nature' [21]. Although marginalized, those utopian movements participated in the maintenance and renewal of small-scale agriculture as well as direct selling, as they were closely tied to organic agriculture, and contributed to the creation of collective farm shops in the 1970s, especially in the south-east of France [22].

By the 1980s in France, direct selling was being developed by small to medium-size farms as a source of revenue diversification, independent of activist issues; the percentage of farms practicing direct selling increased from $19 \%$ in 1979 , to $27 \%$ in 1989 [23]. Direct selling was often conducted by farmers' wives, who, in most cases, did not benefit from an official status [24]. However, this activity was little recognized by agricultural organizations and in public policies, and became still less recognized as time went by, and faced with economic crisis, direct selling became a way-and, in some cases, the only way-of maintaining activity for some farmers [25]. Acknowledging the role of direct selling would have presupposed the recognition of both the limits of the agro-industrial model and the contribution of women and new-comers to agriculture.

In the 1990s, many little farms disappeared and the percentage of farms practicing direct selling dropped to $15 \%$, while local open-air markets were dominated by retailers who procured from wholesalers and long chains. However, the environment was set to change in the 2000s. Firstly, the activist dimension of direct selling was renewed and re-energized with the creation of the first AMAP, directly inspired by the solidarity purchase groups that had developed in Japan (teikei) and North America (Community-supported agriculture) [26]. The development of this system benefited from the mad cow crisis which, more broadly, prompted many consumers-not just activists-to seek more guarantees for food through labelling or by procuring directly from producers [27]. Renewed consumer interest in direct selling, created by a preoccupation with safe produce, prompted the acknowledgement of 'short food chains' by policy-makers: in 2009, 'short food chains' were officially defined as 'selling systems involving no more than one intermediary' by a working group set up by the Ministry of Agriculture representing the diverse stakeholders in these chains, and their development was supported through a specific national plan. The Ministry privileged direct selling, but the focus on 'short food chains' was a way of promoting local procurement in food catering (even if local procurement in food catering often presumed more than one intermediary, as will be demonstrated in a second step, pushing the Ministry and local authorities to also highlight 'proximity food chains'). The development plan included, notably, support for specific studies that aimed to define the diversity of these chains clearly.

\subsection{The Rediscovery of Diversity, Challenged by Issues of Sustainability}

For the first time, questions regarding short food chains were included in the French National Agricultural Census in 2010. This revealed that $20 \%$ of farms (about 100,000) were involved in short food chains. Short food chains, following the official definition in France, have a maximum of one intermediary. More generally, their diversity can be assessed by bringing together the number of 
intermediaries (0 to 1 ), the individual vs. collective dimension, and the geographical distance between producers and consumers (Figure 1). The census demonstrated that direct selling in farms and in open-air markets represented the short chains most used by farmers, far ahead of AMAP and local procuring in food catering, even though these were widely mediatized. For $40 \%$ of these farms, short chains represented more than three-quarters of their turn-over; for $10 \%$ of the farmse in short chains, the latter represented less than $10 \%$ of their turn-over. Short chains were for the most part developed in specific regions (overseas territories, Corsica, the south-east of France) and in specific sectors (honey, fruit, and vegetables). Farms in short chains were smaller than those in long chains (with an average size of 39 hectares as opposed to 73), represented a greater labor force (1,9 FTA (Full-Time Equivalent; 1 FTE corresponds to the annual work of one full-time worker) vs. 1,4), and were more associated with organic agriculture (10\% vs. $2 \%)$.
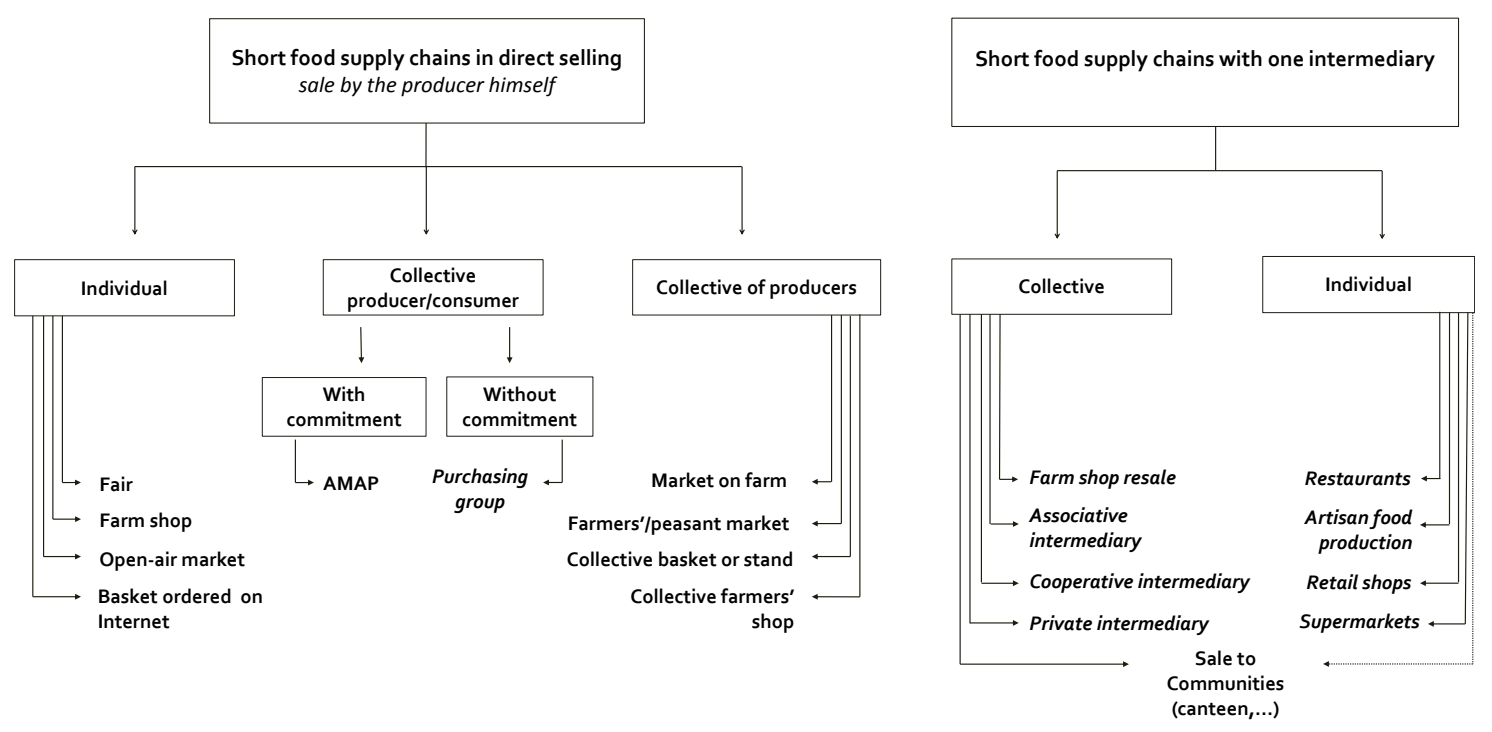

Figure 1. Diversity of short food chains in France in 2016. (Source: authors, in italics, chains not necessarily local.)

In parallel to this survey, the Ministry of Agriculture dedicated specific funds to generating new insight into these chains: one of the most urgent requests, from the Ministry as well as from professionals, was to get technical and economic references to support the increasing number of people, beyond activists, entering farming with the immediate intention of selling in short food chains, as well as the reorientation of farms looking to diversify their outlets because of the economic crisis affecting long chains that had been enduring for several years. Through a broad national set of enquiries, different types of business and technical models were identified [28-30] which confirmed the spread of short chains among 'conventional' farmers as well as their importance in the renewal of the agricultural profession. In parallel, public funds were set aside to implement a national survey of consumers, in order to detail their practices regarding short food chains: in 2013, $42 \%$ of respondents declared they had bought food in short chains in the month preceding the enquiry [31]. This result was consistent with other studies showing an enduring diversification of food procuring sources by consumers, leading to a decrease in supermarket market shares in France [32]. Open-air markets were revealed to be the most popular short chain, even though they are not entirely short, as retailers for the most part still procured from wholesalers. Furthermore, while consumers buying in short chains long term ( $>5$ years) were revealed to be older, well-educated, and middle-income, new consumers ( $<1$ year) were younger, less educated, and with a lower income. While the first category was consistent with the profile highlighted in many studies on alternative food networks consumers in industrialized nations $[26,33,34]$, the second confirmed that the process of diffusion in short chains in France went beyond new entrants among farmers. 
In the French context, where short chains were both traditional and being renewed by alternative forms which were being used more and more by non-activists, from producers to consumers, their contribution to the development of (more) sustainable food systems had now to be examined. On the one hand, pioneers of alternative food networks stressed the risk of the 'conventionalization' of short chains, as in the case of organic agriculture, whose spread in some regions and countries had led to lower standards of sustainability, particularly relating to production methods [35]. However, no general data was available to confirm or disconfirm this hypothesis in France, while the official definition did not include any criteria relative to production. On the other hand, some authors highlighted interest in the coexistence of different forms of agriculture and food chains for food system sustainability: in this case, the focus was often on food security [36]. The coexistence issue was also considered in research into 'hybrid' systems combining the characteristics of long and short chains, as in the case of local procurement in food catering [4]. Nevertheless, analyses stopped short of a longitudinal assessment of the impact of this coexistence or of these hybrid systems-as other expressions of short chains diffusion-on ordinary actors: on consumers, who procure in different food chains, but also on 'conventional' farmers and on local French policy-makers who had latterly appeared to show stronger and stronger support for the development of short chains $[37,38]$. To what extent could their entry into short chains change their representations, practices, knowledge, and expectations about their food system, and more precisely, its agricultural dimension? To assess those changes, we propose to use economic sociology theory, in which actors are seen to evolve in relation to their environment.

\subsection{From Embeddedness to a Relational Approach to Changes in Short Food Chains}

The notion of 'embeddedness' has often been used to characterize alternative local food networks in opposition to the agro-industrial model [1,39]: while the latter is associated with anonymous, 'cold', and often unfair relations, local food networks have been presented as favoring personal, authentic, trusting, and fair relations. Thus they are 'embedded' in (close) social relations while the agro-industrial model represents the dis-embedding of the food sector from social structures. A parallel can thus be drawn with the historical process highlighted by Polanyi: the separation of the market economy from the social sphere, following the industrialization of Western nations at the beginning of the 20th Century [15]. However, even the agro-industrial model remains embedded in social structures, although these are different from those which tend to characterize alternative food networks. The notion of embeddedness, more than being a (positive) characteristic, is an analytical framework that has been developed in economic sociology, in which economic actions are considered to be influenced, both in their forms and their results, by the social environment of actors. In particular, in the English-speaking world's tradition of economic sociology, revived by White and Granovetter in the 1970s [40,41], social relations are thought to be powerful factors of influence through their function as vectors of information, learning, social control, cooperation, and competition, which encourage innovation as well as lock-in processes [42,43]. In France, where short food chains are spreading, we have adopted this idea in order to analyze what the social relations between actors are, without those relations being necessarily positive, and to what extent they influence ordinary actors' practices and knowledge, particularly relating to agriculture, through a case study of an open-air market which has developed over time as a 'hybrid' food chain.

\section{Material and Methods}

The case under study is of an open-air market located in the South of France, in the small town of Grabels, (7000 inhabitants), situated in a dense peri-urban area $10 \mathrm{~km}$ to the north of a big city, Montpellier (300,000 inhabitants). This market was set up in 2008, with the help of a researcher from the National Institute for Agricultural Research, who has coordinated the redaction of this paper. Newly elected in 2008, the local authority thought a market would be a good tool to strengthen social ties within its sleepy town. Moreover, they wanted to improve access to fresh and affordable food for the middle to low-income inhabitants of the town through this market. Thus, the creation of the market 
was driven by preoccupations associated with 'living-together', and aimed to satisfy the individual basic needs of inhabitants from its inception. There had been no particular prior interest in local agriculture or food, still less in alternatives to the agro-industrial model.

This market rapidly suggested itself to the researcher as a good example of an 'enlarged study case'. Following Mitchell, a 'case' (or 'social situation') is defined as 'a detailed examination of an event (or series of related events) which the analyst believes exhibits (or exhibit) the operation of some identified general theoretical principles' [44]. From this definition, a narrative of an event, or a series of events, does not necessarily constitute a case study. Mitchell distinguishes three kinds of cases: cases used to illustrate more general phenomena; cases in which an event, or a series of events, reveal how the general principles of social organization express themselves in specific contexts, and cases which fall within the scope of a larger case study and correspond to the longitudinal analysis of a social situation, which is better able to identify processes and the string of events. Whatever the choice, according to Mitchell, the selection of a case must be done on the basis of its power to enlighten, rather than on its typicality, and a case study is only of interest if it uses a theoretical model which confers generality to the case. In this perspective, the Grabels market was considered to be a case suited to a longitudinal assessment of the role of social relations in the development of practices and knowledge, in a re-territorialization initiative within an urban food system.

Further, the case was studied using an intervention approach to research. This can be understood as an extension of action research: first used by Lewin in his field research into group dynamics [45], action research has since been adopted by different disciplines and along diverse modalities [46]. Researchers using this approach share the conviction that action research is not merely a method, rather, it is both a scientific approach that stems from 'the meeting of a wish for change and a research intention' [45], and a democratic process involving the participation of non-researchers in problem identification as well as in the production of scientific and practical knowledge. Intervention research, which has primarily been developed in management sciences, relies on the same principles. However, while action research limits itself to 'preparing a group to change' [45], intervention research continues up to the formalization of the change brought about by the actors and the construction of management tools to facilitate the implementation of this change [47]. In both action and intervention research, nevertheless, 'researchers have to remain researchers' [48], in other words, 'make the field speak' by bringing out actors' objectives and logic, and then relaying this logic and these objectives back to partners to help them to reach their own conclusions. They absolutely must not become prescribers. Working in a team, and alternating participation (attachment) with observation and distancing (detachment), helps researchers maintain their role [49]: the Grabels market was observed and followed in this way, through a collaboration between a researcher and long-term students who alternated the tasks of conducting interviews, observation, mediation, and co-conception. Two of them have been involved in the redaction of this paper.

Since its creation, the open-air market had been managed by a specific team (from 5 people before its creation, to 10 after), and these we followed by observing and participating in their meetings (about four or five per year), and by regular individual face-to-face interviews with members of the team. In the same way, the direct participants in the market who sell products there were regularly interviewed (producers, artisans, retailers; about 30 persons), and some of their product and raw material suppliers were the subject of occasional interviews (about 30 people). In parallel, we followed a panel of 20 consumers for six years (following the implementation of the labelling system) and conducted occasional interviews with larger samples of consumers. The market attracted 400 customers every week in 2008 and this increased to 700 by 2015, which amounts to between 1500 and 2000 consumers, including their families who also eat the produce. Initially, we tried to have a representative sample covering diverse criteria (age, sex, income), and in the later years, to enable us to analyze the impact of short chain diffusion, we focused on recent consumers who were known not to be concerned by agricultural or sustainability issues before entering the market. In all cases, we asked people to explain to us what they did regarding food and their food system (practices), why they did 
this (justifications, which may include values, habits, constraints, knowledge, and above all, according to our theoretical frame, social relations), if they had changed their practices and/or relations recently or not (especially since they had entered the market), why or why not, and with what effects for them (particularly concerning what they knew about and wanted, as regards their food and food system).

At the same time, in order to cross-reference practices and knowledge with social relations, we developed a qualitative and quantitative network analysis to assess the evolution of diverse relations (dialogue, advice exchange, friendship) and 'non-relations' (conflict, broken relations, observation) more precisely [50], as regards food and food systems: between the direct participants of the market (complete network) and between specific individuals (ego network) [51]. Our longitudinal case study is detailed below through the trajectory of the market, and will illustrate how some events caused this market and its stakeholders to evolve, notably by creating or disrupting some relations. The results also include how this market influenced actors and institutions on a larger scale, towards a renewed way of conceiving the transition of urban food systems towards a more sustainable agriculture.

\section{Results}

\subsection{First Period: The Discovery of the Issue of Food System Re-Territorialization}

In 2008, the newly-elected local Grabels authority wanted to create a market with the aim of strengthening social ties and making fresh and affordable food available. The Mayor delegated this mission to a small voluntary team of Grabels inhabitants who supported his election, and the team was supervised by one of his deputies. At this time, in a national context in which both food safety and short food chains were generating growing interest, two types of markets were becoming more and more mediatized: organic markets on one hand, and 'farmers' markets' reserved for producers in which the resale of produce was forbidden on the other hand. However, the team members were clear that they did not want the former, as it was 'too elitist', or the latter, which seemed to them to offer too irregular a supply for the creation of a solid meeting point for inhabitants. In Grabels, indeed, the main objective was to promote greater relations between inhabitants in an urban context. Of course, the second objective was also important: that of providing fresh and affordable food. Considering this, a classic open-air market dominated by retailers who sell similar products to supermarkets did not interest the team members. They preferred to support 'local small-scale agriculture', over everything else as a way of being sure of having safe, fresh food. However, they did not know how to proceed, either in the creation of a market or in the recruitment of small-scale and local farmers. One member of the team, a teacher at the Center for Higher Education in Agricultural Sciences in Montpellier, heard about the work on 'short food chains' being done by a researcher who was also associated with this school: she contacted her to get an understanding of these chains, as she herself trained students on biotechnology, purchased food in supermarkets, and was very distant from this field of study. She put the researcher and the team in touch with each other. Everyone agreed that short food chains were a good compromise, as they allowed retailers to procure from producers directly, regroup different supplies, and thus offer a wide range of produce that they knew the origin of and about which they were able to explain the methods of production. The team thus decided to create an open-air market favoring short chains with 0 to 1 intermediaries. The researcher, in collaboration with students, started following the team; at this stage, the market was not yet a case study for the researcher, who was just exploring the situation but offered her help. The team members activated their weak ties to recruit participants to the market, but found out that the region specialized in viticulture and fruit and vegetable production destined for long chains and export. Moreover, they became aware that there were almost no farmers left around Grabels, and no small-scale farmers in particular. They learned that 'local' artisans procured most of their raw materials from wholesale markets. Through new dialogue ties concerning food systems, they came to realize how the urbanization process and the implementation of the agro-industrial model had been shaping their region. 
This made the process of recruitment difficult, and the team discovered the issue of food system re-territorialization with its challenges and difficulties. Through their weak ties, team members got in touch with larger-scale farmers who specialized in a limited range of products, and were in the process of reorienting their outlets towards short chains. At this point, as these farmers had difficulty in explaining their situation, the researcher and/or her students acted as spokespeople. As representatives of 'middle-agriculture' [8], which was too big to be socially integrated in alternative food chains, and too small to be competitive in the context of growing competition from farms from other European countries, these farmers faced economic and technical difficulties: their production was no longer adapted to the agro-industrial model, nor did it conform to consumers' basic expectations regarding short chains (diversity, taste). Moreover, as confirmed by a network analysis, they did not benefit from advice from agricultural extension services which is aimed at larger farms, nor did they benefit from alternative agriculture organizations, because they were too associated with the agro-industrial model. Further, they got no support from agricultural public policies. Although these farmers did not correspond to the 'image' they were looking for, the Grabels team members, away from problems in relation with agriculture, started to understand the situation of these farmers. The market was finally created in 2008 with 20 participants, including 10 producers from diverse sectors (vegetables, fruit, olive oil, goat's cheese...), 5 retailers, and 5 artisans, some of them from more than 100 kilometers away. The Mayor enlarged the management of the market to include the city director of legal affairs, three participants in the market (two producers and one artisan) and two consumers in addition to the initial team, in order to ensure local inhabitants' satisfaction. 'Ordinary' consumers who were unrelated to alternative issues were chosen to represent Grabels general population. The researcher was invited to take part in the enlarged management committee, and she discussed the conditions with its members: the Grabels market constituted a 'case study', in a broader intervention research program dedicated to producing new knowledge on short food chains; its members, partners of the research, and producers of knowledge, and not 'subjects' of an experiment as in some experimental approaches developed in social sciences [52].

The committee needed to write a charter in order to restrict market access to sellers favoring short and local chains and thus, they hoped, to guarantee fresh food. To enter the market, sellers had to sell chiefly their own raw produce, or produce bought through one intermediary, or to offer chiefly processed food mostly made with raw materials supplied directly to producers. Moreover, produce and raw materials had to come from a distance of no more than 150 kilometers. Nevertheless, the market was open to small quantities of produce from long chains, as the committee felt that some essential products—such as leeks, garlic, and lemons—could not be produced easily within this perimeter. As to production methods, as most of the committee members were urban and did not know anything about agriculture, they limited their requirements to the basic standards of 'respect for environment and animals, and good labor conditions', which remained at this point, theoretical. A new event, challenging 'trust' ties, would cause the committee's and the farmers' relations with agriculture and sustainability to evolve.

\subsection{Second Period: Crisis of Trust and Addition of the Sustainability Issue}

The market started well, with a high level of satisfaction among consumers on the subject of social ties and fresh food. Nevertheless, two of the market producers did not respect the 'moral' contract behind the charter: the first of them displayed beautiful and tasty fruit, attracting customers by offering free samples, but then sold blemished and not-so-tasty ones, especially to less alert old people, that had been hidden behind the high quality fruit. The second produced goat's cheese from frozen milk bought in Spain. In the first case, consumers complained directly to the committee; in the second, the information came from other market producers, illustrating how social control between peers is a key component of collective action in market dynamics as well [42,53]. The committee realized that even animal produce is seasonal: in goat's cheese production, a break in milk production is needed to allow kids to feed. Techniques may be used to extend, and thus seasonally adjust the production but 
is this 'natural' or not? The committee discussed this and local experts contacted by the researcher confirmed that the market goat's cheese maker used these techniques. Under any circumstances, the committee felt that this producer could not stay on the market as he had lied by telling them that his cheese was made from his own milk production. More broadly, from explanations from this expert and from the only organic farmer selling on the market, the committee learned how out-of-season production relies on specific techniques inherited from an agro-industrial model requiring a high level of input, and these techniques struck them as 'not natural', 'industrial', 'damaging', and potentially 'dangerous'. They thus expressed their new vision of 'agricultural sustainability' by deciding to make the charter stricter in order to only secure seasonal produce, from fruits and vegetables to animal production, that came from low-input agriculture and non-industrial production methods. Further, the committee realized that the market needed more control, as direct ties with producers were not sufficient to get guarantees. Indeed, ordinary consumers were trusting sellers without question. While the fruit producer and the goat's cheese maker were excluded from the market because they were considered to be 'cheats', the other sellers, including the middle-agriculture farmers, had to adapt their supply in order to fulfil the new criteria. This pushed them to diversify both their production and their professional relations with local producers outside the market, to enable them to offer a wide range, while respecting the seasons.

These 'affairs' and their effects on market supply increased consumer doubts: could they be sure that produce was safe, and that it came from short chains? Negative rumors spread through local networks, and some customers left the market. As a consequence, in order to reassure consumers, the deputy mayor in charge of coordinating the committee suggested labelling all produce: these labels, which are mandatory in all retail locations under French law, must inform consumers of the nature of the produce, its price, and in the case of fruit and vegetables, its country of origin. For raw produce, where doubts where strong, the deputy mayor suggested indicating, through the use of colored labels, that the product came from a short chain and respected the agricultural sustainability criteria as defined by the committee and inserted in the charter. This idea led the committee members to participate in the development of a new labelling system, and the research team helped them to formalize it. A green label on produce indicated direct selling by a producer, transportation from no more than from $150 \mathrm{~km}$ outside Grabels, a respect of seasons, production without industrial techniques and with decent labor conditions, and affordability. For the committee, the green color was a way of informing consumers that they could buy the product without question. An orange label indicated that produce was being sold by intermediaries who had bought them directly from a producer personally known to them, or from a group of producers that they could guarantee; besides this, all other green label criteria applied to the orange label too. As with traffic lights, orange was used to encourage consumers 'to be careful', and to question the intermediary about the producer behind the produce. Other produce from long chains and/or not respecting the defined sustainability criteria were labelled in purple rather than red, as the committee did not want to signal that they were forbidden or dangerous, they just wanted to make consumers 'think'.

Implementing of the labelling system was not easy; the committee had to convince the sellers, who were now more numerous ( 30 permanent, about 30 occasional), and this prompted the non-farmer members to learn more about agriculture and to further appropriate their local food system. Proud of innovation they had built collectively on the deputy mayor's original idea, they also explained its meaning to their friends and neighbors, and this increased their standing in the community by giving them the new role of adviser. The labelling system emerged as an intermediary object [54], both a source of new knowledge and of new relations between stakeholders. Importantly, producers also became proud to take part in the innovation, and sped up the diversification of their production with the help of advice from more advanced peers in order to have more green labelled produce and/or extended their relations with local colleagues in order to have more orange labelled produce. The market entered a third period, where its impact took on a new dimension, both locally and nationally. 


\subsection{Third Period: A Tool of Food Democracy for Urban Food Systems}

The implementation of colored labels on all produce offered in the market satisfied many of the consumers who had not dared to question sellers. Its application was controlled by the committee, thus adapting participatory guarantee systems which had been experimented with internationally in organic farming, and in Nature and Progress (a private trademark carried by a network of organic famers following a stricter guideline than the French official organic label) and AMAP networks in France [55]. Control nevertheless remained a touchy issue which presumed skills and information from controllers, and this prompted more technical discussions within the committee, between the urban representatives of the local authority, and consumers and producers. However, the most efficient way of correcting deviations by sellers remained feedback from consumers to the committee on one hand, and social control between sellers on the other. Indeed, consumers appeared to pay more attention to produce after the implementation of colored labels, and to favor those which were labelled as short chains (green, orange). Although most remained lacking in the skills to be sure of deviations, they now had the confidence to let the committee know their doubts, either directly, or through a friend who was in contact with the committee. In this way, the labelling system was not only a tool of information and control, it also assisted consumers' expression regarding their food system.

At the same time, the research team and the mayor of Grabels presented their common experiment to their respective networks, and this interested different media, both national and European. Several local authorities and producer and citizen associations got in touch with the Grabels committee in order to apply the system in their territory. These requests prompted the committee to protect the initiative, the labelling system of which was only the most visible part. A collective trademark to include the charter, the labelling system, and the participatory control was proposed, for free but monitored use. As public institutions and partners, the research institution and the local authority were chosen as the co-owners of the trademark, which could be applied to open-air markets and retail shops which mixed different chains throughout France. However, as food systems differ from one region to another, the researcher pointed out that criteria for 'local' and 'sustainable' may not be the same as it was in Grabels: the Grabels case had demonstrated how the criteria had been negotiated from the constraints and resources of agriculture around Grabels on one hand, and from the priorities of the local committee members on the other. Moreover, these priorities had changed and the criteria had been strengthened. Whilst maintaining the objective of signaling sustainable produce from short chains to consumers, the 'framework-trademark', named Ici.C.Local (Innovation for cooperation and information in Local Chains), would therefore need to be appropriated and adapted locally; 'local' and 'sustainable' criteria would have to be defined, from basic principles, by a territorial committee representing the different stakeholders in the food system (producers, artisans, retailers, consumers, local authority and local partners), and revised if wished or needed. As far as sustainability was concerned, however, respecting seasons was kept as a mandatory criterion, as the committee viewed this as the first step towards a more sustainable food system and was proud that their experiment encouraged changes in other regions (see Table 1).

In June 2016, several local committees were in the process of being formed in France, with the objective of adapting the trademark to their territory and applying it to a new market, to an existing market and/or to retail shops. The committees who were the furthest advanced were found in urban food systems, where the gap between consumers and agriculture is larger, while food system re-territorialization emerged as a new electoral tactic for urban policy-makers $[37,38]$. The initiative was also discussed in other countries, notably in Spain and Italy. In every case, the negotiation around 'local' and 'sustainable' was more than anything an opportunity to debate, to learn about the local food system and from each other, and to choose collectively what could be focused on and prioritized locally, in terms of agriculture. For instance, in one case, the committee spent a long time discussing the possible banning of ensiling in the definition of 'sustainable' produce, before deciding that there were more key criteria to fulfil for 'sustainable agriculture'. In parallel, in Grabels, the experiment was extended to include processed products in response to consumers' and artisans' requirements. 
However, the short chain labelling of processed products is much more complex, and challenged the inertia of Europe concerning information about the origin of raw materials-meat, especially-in processed food.

Table 1. Labelling system criteria for Ici.C.Local trademark, adjusted in the Grabels case.

$\begin{gathered}\text { Produce labels for use in } \\ \text { open-air markets and } \\ \text { retail shops }\end{gathered}$
$\begin{gathered}\text { Mandatory criteria in the } \\ \text { framework-trademark, which } \\ \text { must be respected in every case }\end{gathered}$
$\begin{gathered}\text { Mandatory criteria in the } \\ \text { framework-trademark, which } \\ \text { should be adjusted locally }\end{gathered}$

However, the diffusion of the trademark was not a peaceful process and provoked some tensions between institutions and professional organizations involved in agriculture and/or regional economic development. Some were owners of commercial trademarks that indicated 'farm produce' or 'local/regional produce', and they felt that Ici.C.Local competed with their brand. In truth, Ici.C.Local is compatible with and complements other official labels, quality signs, and trademarks, as has been proven in Grabels. Further discussions with institutional actors revealed that the problem was not commercial; they were troubled by the spread of the two main principles behind Ici.C.Local: transparency and participation. In their cases, the criteria were not necessarily shared with consumers and the latter did not participate in defining or revising them. While the two principles are not troubling when used in alternative systems like AMAPs, for some institutions, they represented a threat when applied to 'ordinary' urban people and open-air markets, of which there are more than 8000 in France.

\section{Discussion}

\subsection{Main Points of Discussion in Research into Alternative Food Chains}

This case study highlights how local urban policy-makers and consumers little connection with agricultural issues have started understanding and appropriating the challenges of food system re-territorialization. The hybrid open-air market, which combines rules from conventional markets (here opposed to 'alternative' food chains, and not to the organic sector), such as mandatory information labels on all produce, with alternative food networks privileging short chains [4], is the result of their learning processes and negotiations between what they want and what can be done in their region in terms of farmers, artisans, and retailers. The now more experienced Grabels local authority is extending the market experiment, and is currently involved in a project installing new farmers in the town, using lands it has bought and will rent to newcomers. The case study thus demonstrates how the re-territorialization of the food system is shaped and given meaning by a specific context. It also demonstrates, using a longitudinal approach, the steps through which the initiative has evolved from electoral preoccupations towards an 'alternative'. In this sense, while contributing to the literature stressing the importance of contextualizing alternative food initiatives in terms of place and history [56], 
our case study directly addresses more recent research on the transition of (conventional) food systems towards more sustainable ones [57].

Moreover, by focusing on networks, this case study confirms that new relations or content of relations, encouraged by the market, have played a key role in this double process of re-territorialization and transition: through recruiting sellers to discussions within the committee and between friends on market day, interpersonal relations have procured information and advice which have constituted, in many observed cases, resources for thinking and acting differently in relation to agriculture and food. This result may not seem original, as research into alternative food networks also highlights how people who are more concerned about sustainability issues influence and teach others about these issues [58]. However, these studies tend to focus on the influence on consumers by the leaders of the initiative, considered to be or described as 'moral entrepreneurs'. In Grabels' case, influence and learning relations do not express any specific strategy by anyone and are distributed among the participants. The advice network analysis revealed how some actors emerge as 'experts' in specific contexts and regarding specific questions [42], although they may not have been considered as skilled and/or leaders before, and may not be considered as a reference or a model thereafter: for instance, the organic farmer selling in the market appeared as a source of knowledge regarding seasonality, while farmers preferred to discuss the diversification of their production with another producer, even though they are 'conventional'. Moreover, while research into alternative food systems often focuses on consumers who are influenced and trained by moral entrepreneurs [6,58], this case study pays greater attention to farmers, who in this case are mostly conventional farmers reorienting their distribution chains. Here, the case study has relativized the pressure of (urban) consumers, which has been highlighted in the rare research into producers in alternative food systems [59]: the charter, inducing changes in production to better fulfil its criteria, has also been developed by producers themselves, who took part in the decisions about the charter as well.

One may question why 'conventional', 'middle-agriculture' farmers have accepted more constraints in the case of Grabels, in which they have gained, through the committee, the opportunity to express themselves and to oppose. Two main reasons emerge from the study: firstly, they too seem to be proud of taking part in a participative and innovative initiative that values them, and is mediatized, in the region especially, and this motivates them to 'do better'; secondly, the changes (diversification, less use of input) induced by the Grabels market seem to be efficient economically, in Grabels and in their other outlets, all the more so as the transition has been progressive, supported by new advice relations with peers that are encouraged by the market, and has not involved too many costs. The technical and economic conditions of a farm's transition towards a more sustainable agriculture are still little considered by social scientists working on alternative or short food chains. This case study, to which students of agronomy and agricultural economics have contributed, has offered initial insight, but calls for further pluri-disciplinary research, particularly because a larger range of productions are concerned in Ici.C.Local diffusion, among which processed products have opened new challenging questions about conditions of transition: for example, the downsizing of equipment, the maintenance of nearby slaughter houses.

\subsection{Back to Economic Sociology, Going beyond a Relational Reductionism}

Using economic sociology as a framework in this paper, we have focused on the role of social relations in the trajectory of the market and in the evolution of its stakeholders' practices and knowledge, within the experience of their food system re-territorialization. Attention to the content of ties has allowed us to go beyond analyses which tend to idealize 'embeddedness' or 'social ties' in local food chains [60]. Indeed, the 'cheats' have demonstrated that local chains are not necessarily spaces of trust and mutual respect. Moreover, network analysis has also shown that some relations have been broken between the sellers, due to increased competition encouraged by the expansion of the market. Further, this expansion has benefitted from this 'negative' face of embeddedness, as highlighted in economic sociology research into the social construction of markets [61]: by both cooperating with 
each other for the success of the market (contributing to the charter, advice exchanges) and competing against each other, sellers structured and maintained the stability of the market [53].

Nevertheless, in the case of Grabels market, a specific device has played an essential role beyond concrete relations as sources of influence, learning, negotiations, social control, etc.-the labelling system. We have presented it above as an 'intermediary object' [54], leading actors to exchange what they know and want and from whom, and build new knowledge and alliances to achieve their common objectives. The notion of an intermediary object comes partly from the actor-network theory [62], which pays more attention to non-humans, in innovation processes as well as in the construction of markets, than other frameworks in the social sciences and in sociology in particular. Following this idea while questioning the principle of symmetry in the actor-network theory, which consider humans and non-humans in the same manner, Grossetti [63] highlights how 'mediation resources' beyond interpersonal relations, play a major role in economic activities. These resources may be rules or devices formally and ex ante dedicated to facilitating coordination between actors, without them having to be tied to each other; these resources may also be objects or persons contributing to the coordination ad hoc, without having been considered in this light before. In the case of Grabels, mandatory labels on products such as can be found in every open-air market or retail shop, have been transformed in mediation resources; their efficiency goes beyond the local situation: as these resources are both easy to access and supportive of two main principles of transparency and participation, they have emerged as new coordination devices on a larger scale as being a democratic way of supporting the transition of food systems, in urban situations in particular.

Although not original in the intention, this case study has ended by intersecting with the large body of literature on food labelling. This literature has been boosted by the proliferation of food safety and quality labels since the 1990s in industrialised nations, and their spread to developing countries in response to consumers' concerns and/or as a means of market differentiation; in both cases, with the growing involvement of the private sector [64]. Bearing in mind this literature, our results can be viewed in the context of two lines of thought: firstly, regarding alternative food chains, labels have been shown to support the reconnection of production with consumption in 'extended short chains', as exemplified in the case of AOC/IGP cited in introduction-although no longer considered as alternative food systems in France-while face-to-face and proximity short chains rely on personal relations [65]. Moreover, in Europe, labels dedicated to these alternative chains appear to combine attributes of produce, place, and process [66]. In Grabels, the label emerged as necessary to reassure consumers, despite direct relations with producers. Furthermore, the label guarantees that sellers know the produce they are offering in detail rather than guaranteeing (local) origin or (sustainable) produce or processes; it also guarantees that their close relations with the produce have been controlled locally, by a private-public committee which thus represents both individual and general interests. These differences confirm that the Grabels market has not been conceived and built as an alternative food chain, even though it is for the most part short; they can also be understood from a transition perspective, in that new kinds of labels and modalities of control (participatory, decentralized, private-public) may be relevant in supporting the 'de-conventionalization' of food systems. This idea leads to a second line of discussion: to what extent can labels realign behaviors along social and/or environmental objectives [67]? On one hand, some research has indicated consumers' limited use of eco-labels, especially when these consumers are not much concerned by the sustainability issue [68]. On the other hand, other research has shown how labels can support the development of a reflexive consumption by non-activists, from examples of milk labelled 'does not contain hormones' [69], to 'GMO-free' labelled produce [70]. The issue is nevertheless often considered in situations where labelling induces a higher price, which may limit its impact on practices [68]. In any case, in Grabels, where the introduction of labels did not increase prices, their impact appears less due to the label in itself than to the local social dynamics it has encouraged. This result calls for more contextualized and long-term analyses of food labelling, in the context of a rise in participatory guarantee systems [55], 
in order to facilitate a debate on what kinds of labels can support the emergence of a 'food democracy' and in what way, as well as-or instead of-neoliberal governance [71].

\subsection{Building Food System Re-Territorialization and Transition through Food Democracy}

The concept of 'food democracy', which was introduced by Lang in the 1990s, has emerged as a way of counter-balancing corporate firms' increasing control of food systems in the face of State disengagement, as well as countering the lack of consumer participation in these systems [12]. The need to democratize food systems by encouraging the participation of members of the public in its management is not merely a policy issue if food is considered as 'a locus of the democratic process' as opposed to 'a tool of control' for consumers. For Lang, it is also a concrete way of encouraging access to healthy food that is produced in a sustainable way to everyone. Hassanein [72] develops the concept by tying collective actions enhancing the role of citizens in food systems more closely to the collective definition of 'sustainability', through social movements and initiatives from civil society. She demonstrates that education is needed to empower consumers to be informed and active, and take part in the development of solutions to common problems, in agriculture and cooking as well as the culture and practice of democracy. Thus "food democracy is not only a goal or endpoint, additionally it's the processes used in achieving food democracy which are critical to our understanding of it" [72]. However, the few concrete examples of this concept there are relating to alternative food networks [73], and are re-described as 'civic food networks' [74] as a consequence, while the conditions for involving 'ordinary' actors and making them change their practices are not further studied, as stated in the introduction. Of course, the Grabels case study is not in itself sufficient to produce robust material on this issue, however, following up on other groups applying Ici.C.Local presents an opportunity to going further: not only in the matter of ordinary actors' participation but also in their 'personal transformation' (self-confidence) within the initiative which may influence-positively or negatively-their participation. Indeed, in Grabels, the pride of taking part in an innovative system that is spreading to other territories, as well as being partners of a research study, has been a key factor in the process of transition.

In another perspective, the Ici.C.Local trademark, formalized from the Grabels market, may be understood to be one possible approach to developing 'Territorial Food Projects' (Projets Alimentaires Territoriaux) in France: promoted by the State in the Agricultural Law of 2014 (Loi d'Avenir Agricole), and currently being strengthened by a new law on 'territorial anchorage of food'. Proposed by the Green Deputy B. Allain, this law aims to 'develop a juridical environment that encourages the local anchorage of food'. Accepted by the French national Assembly in January 2016, the law was approved by the Senate as far as relocalizing food goes-although the Senate rejected the proposal to impose more organic food on public food catering. Territorial food projects have been construed as local concertation around food, with the aim of building more sustainable food systems. This context will produce new case studies that will test how diverse expressions of food democracy such as Ici.C.Local can have a greater impact. It will also provide new resources for comparing urban and rural situations on one hand, to questioning the democratic and transformative dimension of more institutional devices such as city food councils, 'recovering' the local level in industrialized countries [75], on the other.

\section{Conclusions}

Local food networks have for the most part been studied through initiatives in which actors define themselves by their difference from, or opposition to, the agro-industrial model—or 'corporate food regime' - which is still dominating the food industry [76]. However, as already highlighted by recent works on the 'agriculture of the middle' [7-9], a larger reality can be observed in these networks. This is particularly true in France where direct selling has been a traditional system of distribution, and where 'short food chains' have been officially defined and are supported by recent public policies. The entry of 'ordinary' actors, from producers to consumers, and including local policy-makers, has challenged the capacity of these short chains to encourage the transition towards more sustainable food systems, 
particularly in urban and peri-urban areas. By considering the case study of an urban open-air market, and with the help of input from economic sociology, we have illustrated how interpersonal relations are a source of new knowledge which enables actors with little or no awareness of agricultural and/or sustainability issues, to think and act differently. Assisted by the democratic framework that goes with the creation of the market committee, these relations have also seemed easy to develop because they have not been driven by activists and/or highly skilled people, who often generate relations that are too uneven [42]. We have also demonstrated the essential role of the labelling system as both an intermediary object and a mediation resource, which has contributed greatly to shaping the trajectory of the market and of its participants, notably by generating pride in them. Relations, as well as mediation resources, have proven to be relevant features in the process of transition towards more sustainable practices in the urban food system here considered. As open-air markets are a traditional form of food chain in France, we have therefore shone new light on traditional types of food chain which could be renewed as networks of transition towards sustainable agriculture, particularly in urban food systems, if they are also considered as possible loci of social innovation [77].

Acknowledgments: We would like to acknowledge the participants of the Grabels market for their receptiveness to our follow-up of their initiative, their feed-back on our results and their consent to research publications from our collaboration. We also thank Laura Amalir for her careful English editing of our paper. The research has been funded by INRA, the PSDR program, the Casdar program managed by the Ministry of Agriculture, and the FAO. The Ici.C.Local trademark has been co-funded by INRA and the town of Grabels.

Author Contributions: Yuna Chiffoleau structured the analytical framework, designed the outline of the paper, and coordinated its redaction. Sarah Millet-Amrani and Arielle Canard contributed to the intervention research, alternating tasks as written in the paper. The former focused on producers and intermediaries, the latter on consumers and the local authority. Both took part in the analysis.

Conflicts of Interest: The authors declare no conflict of interest.

\section{References}

1. Maye, D. Moving alternative food networks beyond the niche. Int. J. Soc. Agric. Food 2013, 20, 383-389.

2. Whatmore, S.; Stassart, P.; Renting, H. What's alternative about alternative food networks? Environ. Plan. 2003, 35, 389-391. [CrossRef]

3. Holloway, L.; Kneafsey, M.; Venn, L.; Cox, R.; Dowler, E.; Tuomainen, H. Possible food economies: A methodological framework for exploring food production-consumption relationships. Sociol. Rural. 2007, 47, 1-18. [CrossRef]

4. Le Velly, R.; Dufeu, I. Alternative food networks as "market agencements": Exploring their multiple hybridities. J. Rural Stud. 2016, 43, 173-182. [CrossRef]

5. Goodman, D. The quality 'turn' and alternative food practices: Reflections and agenda. J. Rural Stud. 2003, 19, 1-7. [CrossRef]

6. Deverre, C.; Lamine, C. Les systèmes agroalimentaires alternatifs. Une revue de travaux anglophones en sciences sociales. Econ. Rural. 2010, 317, 57-73. [CrossRef]

7. Feenstra, G.; Hardesty, S. Values-Based Supply Chains as a Strategy for Supporting Small and Mid-Scale Producers in the United States. Agriculture 2016, 6, 39. [CrossRef]

8. Lyson, T.A.; Stevenson, G.W.; Welsh, R. (Eds.) Food and the Mid-Level Farm. Renewing an Agriculture of the Middle; The MIT Press: Cambridge, MA, USA; London, UK, 2008.

9. Fleury, P.; Lev, L.; Brives, H.; Chazoule, C.; Désolé, M. Developing Mid-Tier Supply Chains (France) and Values-Based Food Supply Chains (USA): A Comparison of Motivations, Achievements, Barriers and Limitations. Agriculture 2016, 6, 36. [CrossRef]

10. Nicolas, F.; Valceschini, E. (Eds.) Agro-Alimentaire: Une Économie de la Qualité; Inra-Economica: Paris, France, 1995.

11. Malassis, L. Nourrir les Hommes; Flammarion: Paris, France, 1994.

12. Lang, T. Towards a food democracy. In Consuming Passions: Cooking and Eating in the Age of Anxiety; Griffiths, S., Wallace, J., Eds.; Manchester University Press: Manchester, England, 1998; pp. 13-24.

13. Granovetter, M.; Swedberg, R. The Sociology of Economic Life; Westview Press: Boulder, CO, USA, 2001. 
14. Holleran, C. Shopping in Ancient Rome: The Retail Trade in the Late Republic and the Principate; Oxford University Press: Oxford, UK, 2012.

15. Polanyi, K. The Great Transformation; Farrar \& Rinehart: New York, NY, USA, 1944.

16. Margairaz, D. Foires et Marchés dans la France Préindustrielle; Les Editions de l’EHESS: Paris, France, 1988.

17. Allaire, G.; Boyer, R. (Eds.) La Grande Transformation de l'Agriculture; INRA-Economica: Paris, France, 1995.

18. Langeard, E.; Peterson, R.A. Diffusion of large-scale food retailing in France: Supermarché and hypermarché. J. Retail. 1975, 51, 43-63.

19. Brazda, J.; Schediwy, R. (Eds.) Consumer Cooperatives in a Changing World; International Cooperative Alliance: Geneva, Switzerland, 1989.

20. Colonna, P.; Fournier, S.; Touzard, J.-M.; Abécassis, J.; Broutin, C.; Chabrol, D.; Champenois, A.; Deverre, C.; François, M.; Lo Stimolo, D.; et al. Food systems. In Food System Sustainability: Insights from duALIne; Esnouf, C., Russel, M., Bricas, N., Eds.; Cambridge University Press: Cambridge, UK, 2013; pp. 69-100.

21. Léger, D.; Hervieu, B. Le Retour à la Nature: Au Fond de la Forêt, l'État; Éditions du Seuil: Paris, France, 1979.

22. Deléage, E. Les mouvements agricoles alternatifs. Inf. Soc. 2011, 164, 44-50.

23. Capt, D.; Wavresky, P. Determinants of direct-to-consumer sales on French farms. Rev. Études Agric. Environ. 2014, 95, 351-377. [CrossRef]

24. Giraud, C. Division du travail d'accueil et gratifications dans les chambres d'hôtes à la ferme. Cahiers du Genre 2004, 2, 71-91. [CrossRef]

25. Pagès, A. La Pauvreté en Milieu Rural; Presses Universitaires du Mirail: Toulouse, France, 2005.

26. Lamine, C. Settling the shared uncertainties: Local partnerships between producers and consumers. Sociol. Rural. 2005, 45, 324-345. [CrossRef]

27. Codron, J.-M.; Sirieix, L.; Reardon, T. Social and Environmental Attributes of Food Products: Signaling and Consumer Perception, with European Illustrations. Agric. Hum. Values 2006, 23, 283-297. [CrossRef]

28. Capt, D.; Chiffoleau, Y.; Gauche, A.; Gervreau, G.; Leseigneur, A.; Touzard, J.-M.; Traversac, J.-B.; Diallo, A.; Tozanli, S. Elaboration d'un Référentiel Technico-Économique dans le Domaine des Circuits Courts de Commercialisation. Partie 1: Cadre d'Analyse, Méthodologie et Synthèse des Résultats Légumes et Produits Laitiers en Circuits Courts; Research Report for the Ministère de l'Alimentation, de l'Agriculture, de la Pêche, de la Ruralité et de l'Aménagement du Territoire; INRA-AgroSupDijon: Montpellier, France, 2011.

29. CERD (Ed.) Elaboration d'un Référentiel pour Évaluer la Performance Technique, Économique, Sociale et Environnementale et Favoriser le Développement des Circuits Courts de Commercialisation; Study Report; CERD: Château-Chinon, France, 2013.

30. Bellec-Gauche, A.; Chiffoleau, Y. Construction des stratégies et des performances dans les circuits courts alimentaires: Entre encastrement relationnel et gestionnaire. Rev. Études Agric. Environ. 2015, 96, 653-676. [CrossRef]

31. Loisel, J.-P.; François, M.; Chiffoleau, Y.; Hérault-Fournier, C.; Sirieix, L.; Costa, D. La Consommation Alimentaire en Circuits Courts: Equête nationale; Research Report; Gret-INC-INRA: Paris, France, 2013.

32. Dembo, A.; Colin, J. Enquête Commerce 2012/Comportements et Attitudes des Consommateurs à l'Égard du Commerce Alimentaire; Cahier de Recherche du CREDOC: Paris, France, 2012.

33. Onianwa, O.; Wheelock, G.; Mojica, M. Determinants of Farmer-to-Consumer Direct-Market Shoppers. J. Food Distrib. Res. 2005, 36, 130-134.

34. Zepeda, L.; Li, J. Who Buys Local Food? J. Food Distrib. Res. 2006, 3, 5-15.

35. Guthman, J. The Trouble with 'Organic Lite' in California: A Rejoinder to the 'Conventionalisation' Debate. Sociol. Rural. 2004, 44, 301-316. [CrossRef]

36. Esnouf, C.; Russel, M.; Bricas, N. (Eds.) Food System Sustainability_Insights from duALIne; Cambridge University Press: Cambridge, UK, 2013.

37. Aubry, C.; Kebir, L. Shortening food supply chains: A means for maintaining agriculture close to urban areas? The case of the French metropolitan area of Paris. Food Policy 2012, 41, 85-93. [CrossRef]

38. Bonnefoy, S.; Brand, C. Régulation politique et territorialisation du fait alimentaire: de l'agriculture à l'agri-alimentaire. Géocarrefour 2014, 89, 89-103. [CrossRef]

39. Tregear, A. Progressing knowledge in alternative and local food networks: Critical reflections and a research agenda. J. Rural Stud. 2011, 27, 419-430. [CrossRef]

40. White, H.C. Identity and Control; Harvard University Press: Cambridge, MA, USA, 1992. 
41. Granovetter, M.S. Economic action and social structure: The problem of embeddedness. Am. J. Sociol. 1985, 91, 481-510. [CrossRef]

42. Lazega, E. The Collegial Phenomenon. The Social Mechanisms of Cooperation among Peers in a Corporate Law Partnership; Oxford University Press: Oxford, UK, 2001.

43. Burt, R.S. Structural Holes: The Social Structure of Competition; Harvard University Press: Cambridge, MA, USA, 1992.

44. Mitchell, J.C. Case and situation analysis. Sociol. Rev. 1983, 31, 187-211. [CrossRef]

45. Lewin, K. Action Research and Minority Problems. J. Soc. Issues 1946, 2, 34-36. [CrossRef]

46. McNiff, J.; Whitehead, J. All You Need to Know about Action Research; Sage: London, UK, 2011.

47. Hatchuel, A. Intervention Research and the Production of Knowledge. In Cow up a Tree. Knowing and Learning for Change in Agriculture. Case Studies from Industrialised Countries; Cerf, M., Gibbon, D., Hubert, B., Ison, R., Jiggins, J., Paine, M., Proost, J., Röling, N., Eds.; INRA Editions: Paris, France, 2000; pp. 55-68.

48. Friedberg, E. Faire son métier de sociologue, surtout dans l'intervention. In La Sociologie et l'Intervention. Enjeux et Perspectives; Vrancken, D., Kuty, O., Eds.; De Boeck: Paris, France, 2001; pp. 111-130.

49. Callon, M.; Rabeharisoa, V. Research in the wild and the shaping of new social identities. Technol. Soc. 2003, 25, 193-204. [CrossRef]

50. Chauvac, N.; Cloutier, L.; Defossez, A.; Akerman, G.; De Federico, A. Negative ties, lost ties, latent ties, Introduction to the special issue. Bull. Méthodol. Sociol. 2014, 121, 5-9.

51. Degenne, A.; Forsé, M. Introducing Social Networks; Sage: London, UK, 1999.

52. Banerjee, A.V.; Duflo, E. The experimental approach to development economics. Annu. Rev. Econ. 2009, 1, 151-178. [CrossRef]

53. Favereau, O.; Lazega, E. (Eds.) Conventions and Structures in Economic Organization; Edward Elgar: Cheltenham, UK; Northampton, MA, USA, 2002.

54. Vinck, D. Les objets intermédiaires dans les réseaux de coopération scientifique. Contribution à la prise en compte des objets dans les dynamiques sociales. Rev. Fr. Sociol. 1999, 40, 385-414. [CrossRef]

55. Loconto, A.; Poisot, A.-S.; Santacoloma, P. (Eds.) Sustainable Practices, Sustainable Markets? Exploring Institutional Innovations that Link Sustainable Agricultural Practices with Markets; FAO: Rome, Italy, 2016.

56. Selfa, T.; Qazi, J.A. Place, taste or face-to-face? Understanding producer-consumer networks in "local" food systems in Washington State. Agric. Hum. Values 2005, 22, 451-465. [CrossRef]

57. Spaaragen, G.; Oosterveer, P.; Loeber, A. (Eds.) Food Practices in Transition. Changing Food Consumption, Retail and Production in the Age of Reflexive Modernity; Routledge: New York, NY, USA; London, UK, 2012.

58. Dubuisson-Quellier, S.; Lamine, C.; Le Velly, R. Citizenship and Consumption: Mobilisation in Alternative Food Systems in France. Sociol. Rural. 2011, 51, 304-323. [CrossRef]

59. Maréchal, G.; Spanu, A. Les circuits courts favorisent-ils l'adoption de pratiques agricoles plus respectueuses de l'environnement? Courr. Environ. INRA 2010, 59, 33-46.

60. Galt, R.E. The Moral Economy Is a Double-edged Sword: Explaining Farmers' Earnings and Self-exploitation in Community-Supported Agriculture. Econ. Geogr. 2013, 89, 341-365. [CrossRef]

61. White, H.C. Markets from Networks. Socioeconomic Models of Production; Princeton University Press: Princeton, NJ, USA, 2002.

62. Callon, M. The Sociology of an Actor-Network. In Mapping the Dynamics of Science and Technology; Callon, M., Law, J., Rip, A., Eds.; Macmillan: London, UK, 1986.

63. Grossetti, M. Réseaux sociaux et ressources de médiation dans l'activité économique. Sci. Soc. 2008, 73, 83-103.

64. Henson, S.; Reardon, T. Private agri-food standards: Implications for food policy and the agri-food system. Food Policy 2005, 30, 145-153. [CrossRef]

65. Renting, H.; Marsden, T.; Banks, J. Understanding alternative food networks: Exploring the role of short food supply chains in rural development. Environ. Plan. A 2003, 35, 393-411. [CrossRef]

66. Ilbery, B.; Morris, C.; Buller, H.; Maye, D.; Kneafsey, M. Product, process and place. An examination of food marketing and labelling schemes in Europe and North America. Eur. Urban Reg. Stud. 2005, 12, 116-132. [CrossRef]

67. Golan, E.; Kuchler, F.; Mitchell, L.; Green, C.; Jessup, A. Economics of food labeling. J. Consum. Policy 2001, 24, 117-184. [CrossRef] 
68. Grunert, K.G.; Hieke, S.; Wille, J. Sustainability labels on food products: Consumer motivation, understanding and use. Food Policy 2014, 44, 177-189. [CrossRef]

69. DuPuis, E.M. Not in my body: rBGH and the rise of organic milk. Agric. Hum. Values 2000, 17, $285-295$. [CrossRef]

70. Vecchione, M.; Feldman, C.; Wunderlich, S. Consumer knowledge and attitudes about genetically modified food products and labelling policy. Int. J. Food Sci. Nutr. 2015, 66, 329-335. [CrossRef] [PubMed]

71. Guthman, J. The Polanyian Way? Voluntary Food Labels as Neoliberal Governance. Antipode 2007, 39, 456-478. [CrossRef]

72. Hassanein, N. Practicing food democracy: A pragmatic politics of transformation. J. Rural Stud. 2003, 19, 77-86. [CrossRef]

73. Booth, S.; Coveney, J. Food Democracy: From Consumer to Food Citizen; Springer: London, UK, 2015.

74. Renting, H.; Schermer, M.; Rossi, A. Building Food Democracy: Exploring Civic Food Networks and Newly Emerging Forms of Food, Citizenship. Int. J. Soc. Agric. Food 2012, 19, $289-307$.

75. Stierand, P. Food Policy Councils: Recovering the local level in food policy. In Sustainable Food Planning: Evolving Theory and Practice; Viljoen, A., Wiskerke, J.S.C., Eds.; Wageningen Academic Publishers: Wagenigen, The Netherlands, 2012; pp. 67-78.

76. Friedmann, H. From Colonialism to Green Capitalism: Social Movements and Emergence of Food Regimes. In New Directions in the Sociology of Global Development; Buttel, F.H., McMichael, P., Eds.; Elsevier: Amsterdam, The Netherlands, 2005; pp. 227-264.

77. Moulaert, F.; McCallum, D.; Mehmood, A.; Hamdouch, A. (Eds.) The International Handbook of Social Innovation; Edward Elgar Publishing: Cheltenham, UK, 2013.

(C) 2016 by the authors; licensee MDPI, Basel, Switzerland. This article is an open access article distributed under the terms and conditions of the Creative Commons Attribution (CC-BY) license (http:/ / creativecommons.org/licenses/by/4.0/). 